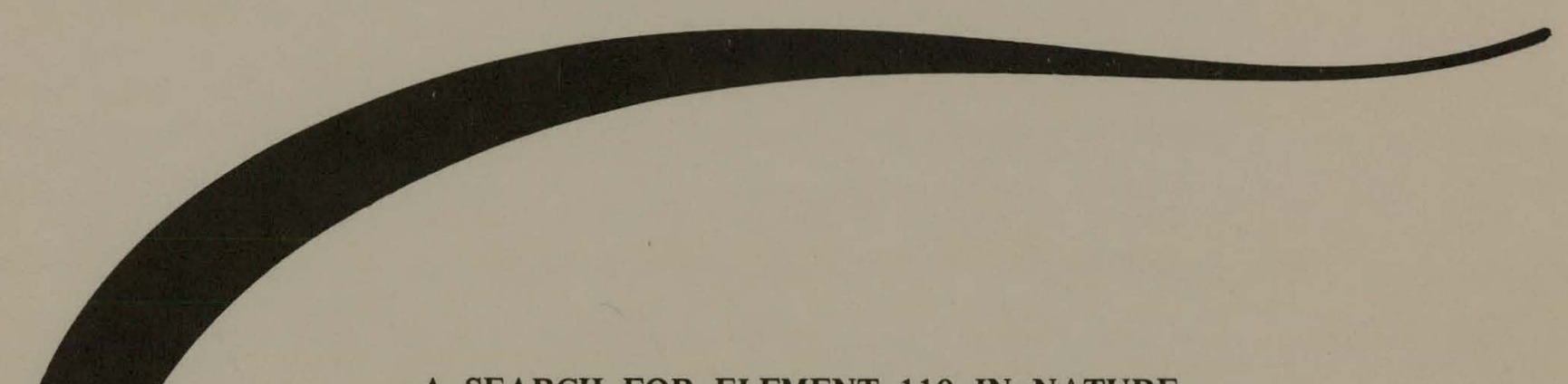

\title{
A SEARCH FOR ELEMENT 110 IN NATURE
}

H. Rodney Martin and Harold W. Miller

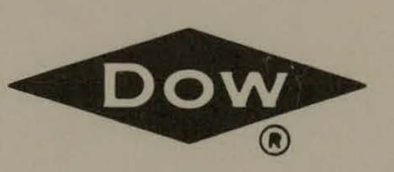

DOW CHEMICAL U.S.A. ROCKY FLATS DIVISION P. O. BOX 888

GOLDEN, COLORADO 80401

\author{
U. S. ENERGY RESEARCH AND \\ DEVELOPMENT ADMINISTRATION \\ CONTRACT AT(29-1)-1106
}




\section{DISCLAIMER}

This report was prepared as an account of work sponsored by an agency of the United States Government. Neither the United States Government nor any agency Thereof, nor any of their employees, makes any warranty, express or implied, or assumes any legal liability or responsibility for the accuracy, completeness, or usefulness of any information, apparatus, product, or process disclosed, or represents that its use would not infringe privately owned rights. Reference herein to any specific commercial product, process, or service by trade name, trademark, manufacturer, or otherwise does not necessarily constitute or imply its endorsement, recommendation, or favoring by the United States Government or any agency thereof. The views and opinions of authors expressed herein do not necessarily state or reflect those of the United States Government or any agency thereof. 


\section{DISCLAIMER}

Portions of this document may be illegible in electronic image products. Images are produced from the best available original document. 


\section{LEGAL NOTICE}

This report was prepared as an account of work sponsored by the United States Government. Neither the United States nor the Energy Research and Development Administration, nor any of their employees, nor any of their contractors, subcontractors, or thcir cmployees, makes any warranty, expressed or implied, or assumes any legal liability or responsibility for the accuracy, completeness or usefulness of any information, apparatus, product or process disclosed, or represents that its use would not infringe privately owned rights.

Printed in the United States of America

Available from the National Technical Information Service

U. S. Department of Commerce

Springfield, Virginia 22151

Price: Printed Copy $\$ 4.00$ Microfiche $\$ 2.25$ 
Printed

June 9, 1975
RFP-2364

UC-34c PHYSICS-NUCLEAR

TID-4500-R62

\title{
A SEARCH FOR ELEMENT 110 IN NATURE
}

\author{
H. Rodney Martin and Harold W. Miller
}

Chemistry Research and Development

CHEMISTRY INSTRUMENTATION

SUBJECT DESCRIPTORS

Elcment-110

Trans-104 Elements

Transplutonium Elements

Separation Processes

Charged Particle Detection

\author{
DOW CHEMICAL U.S.A. \\ ROCKY FLATS DIVISION \\ P. O. BOX 888 \\ GOLDEN, COLORADO 80401
}

Prepared under Contract AT(29-1)-1106

for the

Albuquerque Operations Office

U. S. Energy Research and Development Administration

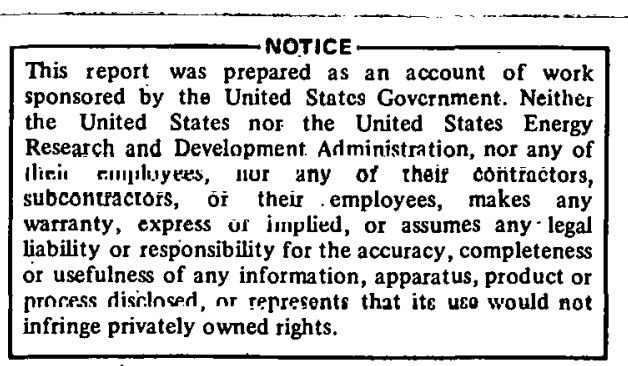


RFP-2364

THIS PAGE INTENTIONALLY LEFT BLANK

ii 


\section{CONTENTS}

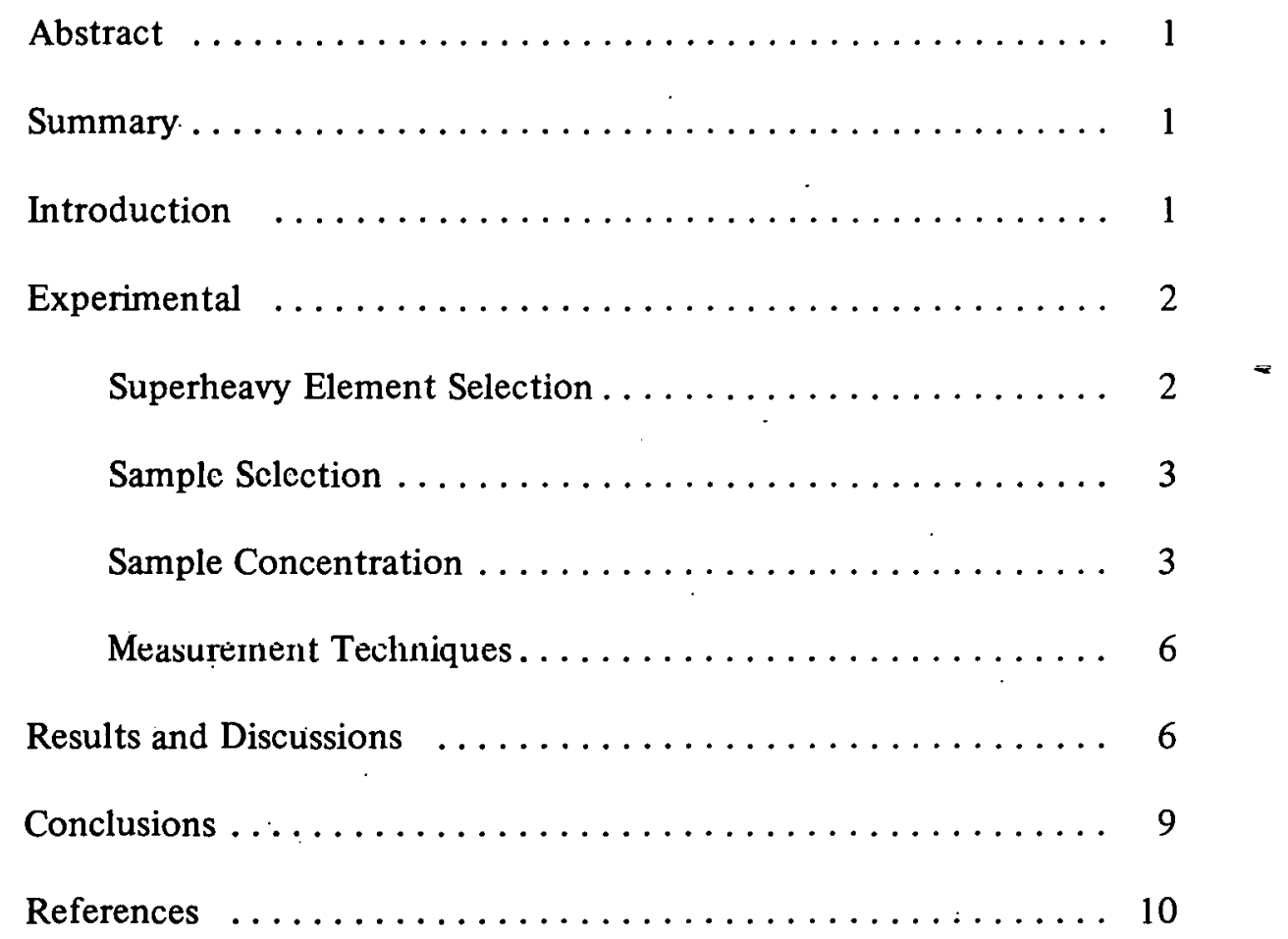


RFP-2364

THIS PAGE INTENTIONALLY LEFT BLANK 


\section{A CKNOW LEDGEMENT}

The authors thank G. T. Seaborg and J. T. Bloom whose interest and support made this study possible. The authors also acknowledge the continued interest and enlightening discussions obtained from O. L. Keller. Thanks also go to the Anaconda Mining Company for their assistance in obtaining some of the samples. 
RFP-2364

THIS PAGE INTENTIONALLY LEFT BLANK 
RFP-2364

\title{
A SEARCH FOR ELEMENT 110 IN NATURE
}

\author{
H. Rodney Martin and Harold W. Miller
}

\begin{abstract}
The results of a search for Element 110 in nature are reported. Techniques for estimating the geological concentration and for chemically concentrating noble superheavy elements are described. An upper limit of $10^{-14}$ to $10^{-15}$ grams per gram of ore is estimated for the abundance of Element 110 , assuming a half-life of $10^{9}$ years.
\end{abstract}

\section{SUMMARY}

In recent years, various calculations have suggested some nuclei with atomic numbers in the range of 108 to 114 may have half-lives sufficiently long for those nuclei to exist in nature. This report describes attempts to detect the presence of noble superheavy elements in nature, with emphasis placed on a search for Element 110 (ekaplatinum).

General considerations employed in extrapolating chemical properties of superheavy elements are discussed as a guide in the selection of favorable geological deposits. A discussion of the formation of deposits containing noble elements is given, and a technique for estimating the geological concentration of noble elements is demonstrated for two of these deposits. A procedure for the selective chemical concentration of noble elements is also provided.

Samples were prepared from five selected platinumbearing deposits and were both alpha and fission counted. The absence of positive fission counting results lead to an estimate of $10^{-14}$ grams per gram $(\mathrm{g} / \mathrm{g})$ of ore as an upper limit for the abundance of Element 110. Alpha spectra from some of the samples yielded unusual results, but the spectra do not offer any positive evidence for the existence of Element 110 in nature.

\section{INTRODUCTION}

Interest in the study of superheavy nuclei began after Myers and Swiatecki. predicated an island of relative nuclear stability beyond the present periodic table. Various theoretical calculations ${ }^{2-4}$ have suggested that nuclei having atomic numbers in the region 108 to 114 may have half-lives sufficiently long for survival since formation of the solar system. Calculations by Nilsson and coworkers ${ }^{2}$ predicted the isotope ${ }^{294} 110$ would have maximum stability against all modes of decay in this region of stable nuclei.

Nilsson, et al., 5 searched for Element 110 in platinum ores with a variety of experimental methods. Wesolowski, et al., ${ }^{6}$ searched for the element in a platinum placer by using neutroninduced fission measurements. The absence of conclusive, positive results in these and other searches ${ }^{7-12}$ suggested that if superheavy elements existed in nature, their abundance must be low. Any search for these elements should therefore consider every possible geological or chemical concentration that could enhance the probability of discovery.

The large uncertainties associated with the half-life predictions in this island of nuclear stability give rise to several possibilities for a detectable superheavy element in nature. These possibilities cover a range of chemical elements from about Element 108, ekaosmium, to about Element 114, ekalead. Efforts in this study were concentrated on the superheavy element with the most favorable combination of half-life, and on geological and chemical concentration probabilities, rather than trying to cover the entire range. This reduced the problem of predicting favorable geological deposits for a variety of unknown elements. 


\section{EXPERIMENTAL}

\section{Superheavy Element Selection}

It is necessary to consider two types of abundances when searching for superheavy elements. The first is the cosmic abundance; the second is geochemical. Both types of abundances are determined primarily by the electronic configuration of the atom. The cosmic production of superheavy nuclei is a matter of some controversy. ${ }^{13-15}$ Provided such nuclei are produced in nucleosynthesis, their abundance is undoubtedly low. This made it seem likely that even under the most ideal conditions, only trace amounts of these elements can ever be found.

The geochemical abundance, which is determined by electronic configuration, bond type, ionic radii, and other properties, determines the overall availability of the elements. For example, if the atomic properties are such that the cation may substitute readily for such elements as sodium, potassium, calcium, and magnesium in a silicate structure, then the superheavy element would be dispersed. Even if it were in the universe in large quantities, the superheavy element would not be concentrated in any mineral and therefore would not be readily obtainable. If the properties were such that the element would be concentrated in a particular mineral or mineral deposit, advantage should be taken of this geochemical enrichment.

Predictions are difficult to made as to the conditions under which an unknown element might be enriched. It would be necessary to extrapolate accurately from the position of the element in the periodic table such properties as valence, bond type, ionic radii, electronegativity, ionization potential, and many other properties, to predict the mineral in which the unknown element would occur. The periodic table can be misleading when used to predict (from family relationships alone) the elemental associates of a new element. For example, it seems unlikely that Element 114 (ekalead) will be found in ore minerals of lead or any other element of Group IV. Even though tin and lead are both in Group IV, they rarely occur together in nature. Tin is found in high temperature (hypothermal) deposits and pegmatites whereas lead usually is found in medium to low temperature (mesothermal and epithermal) deposits; therefore, one would not likely find ekatin (lead) in tin deposits.

Before rhenium ( $\mathrm{Re}$ ) was discovered, ores of manganese were searched for rhenium since both elements belong to the same subgroup of the periodic system. The chemical properties of rhenium closely resemble those of manganese; however, the manner of ncsurrence of rhenium in nature differs greatly from that of manganese. Rhenium is never found in manganese ores but is found in ores of molybdenum (Mo). An explanation given is the isomorphism of molybdenite $\left(\mathrm{MoS}_{2}\right)$ and rhenium sulfide $(\operatorname{ReS})$, and the similarity of the ionic radii of $\mathrm{Mo}^{+4}(0.68)$ and $\mathrm{Re}^{+4}(0.56)$.

It was deemed advisable to search only for Element 110, ekaplatinum for the following reasons:

(1) Theoretical predictions indicated Element 110 had the most favorable combination of alpha, beta, and fission half-lives.

(2) The geochemistry and geological enrichment of Element 110 in nature were more easily predicted, and a more accurate evaluation of the geochemical distribution was possible than for the other superheavy elements.

(3) A chemical concentration technique, discussed later, was available for Element 110. This technique was believed to be less sensitive to variations in chemical properties than concentration techniques designed for other superheavy elements.

(4) The geological conditions for the concentration of Elenient 110 should also bc favorable for the concentration of Elements 108 (ekaosmium) and 109 (ekairidium).

It was far easier to predict the geological occurrence of ekasiderophile elements (ekaosmium and ekaplatinum) in nature than that of the ekachalcophile elements (ekamercury and ekalead). It was even possible to determine a reasonably accurate natural geological enrichment factor for the ekasiderophile elements, an accomplishment impossible to achieve with the ekachalcophile elements. 


\section{Sample Selection}

Theoretical calculations ${ }^{16}$ have indicated that ekaplatinum is even more noble and siderophilic than platinum. It may be reasonably inferred, therefore, that any geological condition under which platinum is concentrated should also concentrate ekaplatinum since chemical properties such as valence states and complexing tendencies are of minor significance in the formation of geologically enriched platinum metal deposits.

The major platinum deposits of the world have been found in either layered magmatic segregations associated with ultramafic rocks or as metallic nuggets derived from the weathering of these magmatic segregation deposits (placers). To explain why certain samples were chosen from specific geologic areas, a somewhat simplified description is given of the conditions under which the geological enrichment of the platinum metals occurs.

For reasons as yet unknown, large masses of molten rock of basaltic composition have risen from the depths of the earth, probably from the mantle, and have formed large sills or lacoliths a few miles below the earth's surface. A graphical representation of the formation of this sill is shown in Figure 1. Since the volume of this complex silicate melt may amount to thousands of cubic miles, the metallic elements contained therein are greatly dispersed and are present only in the parts per million or parts per billion range. As this magma approached the surface of the earth, it cooled. If the magma formed a sill or lacolith, the outer edges solidified rapidly on contact with the cold rocks near the surface. A chilled zone was formed with a chemical composition identical to that of the original basaltic magma, as shown in Figure 2. The rocks of the upper chilled zone are called gabbros or norites and consist of a coarse crystalline variety of basalt.

As the remainder of the molten basalt slowly cooled, a process known as magmatic differentiation took place. The higher melting minerals and elements solidified first and settled to the bottom of the magma chamber under the influence of gravity as shown in Figure 1. Platinum-bearing chromite formed in bands horizontal to the floor of the sill as represented in Figures 1 and 2. This is the most likely area for the concentration of ekaplatinum.

Two deposits of this type are represented by the Stillwater Igneous Complex of Montana and the Merensky Reef, Bushveld Igneous Complex of Transvall, Africa. Samples from the norite and gabbro zone and from the platinum-bearing chromite-harzburgite zone of both of these deposits were obtained for investigation. The differentiated basaltic sill was faulted, uplifted, and exposed by erosion, which made it possible to obtain these samples from the proper zones.

Material from the Stillwater Complex contained $28 \%$ chromium and $0.001 \mathrm{oz}$ of platinum per ton. This sample was investigated for ekaplatinum in a manner described later. The gabbro from the chilled zone contained $0.005 \%$ chromium and no detectible platinum. Since the gabbro represents the primordial basalt before differentiation, an approximate geological enrichment can be obtained for ekaplatinum. The ratio of chromium in the chromite ore formed after differentiation to that in the primordial basalt is $5.6 \times 10^{3}$. This should be a lower limit for the enrichment of ekaplatinum by natural processes in the Stillwater Complex.

A natural concentration factor of $2.5 \times 10^{3}$ was obtained for the Merensky Reef ore although the platinum content of the material analyzed was higher $(0.16 \mathrm{oz} /$ ton $)$.

Samples from two deposits of a slightly different nature were also investigated. These deposits consisted of a magmatic segregation of chalcopyrite and platinum in syenite. One sample was obtained from the Copper King Mine, Cook City, Park County, Montana and contained $0.29 \mathrm{oz}$ of platinum per ton. The second sample was obtained from the Copper Hill Mine, La Plata County, Colorado and contained $0.06 \mathrm{oz}$ of platinum per ton. Finally, platinum nuggets from a placer deposit near Butte, Montana were also investigated.

\section{Sample Concentration}

Although predictions have been made concerning some of the chemical and physical properties of 


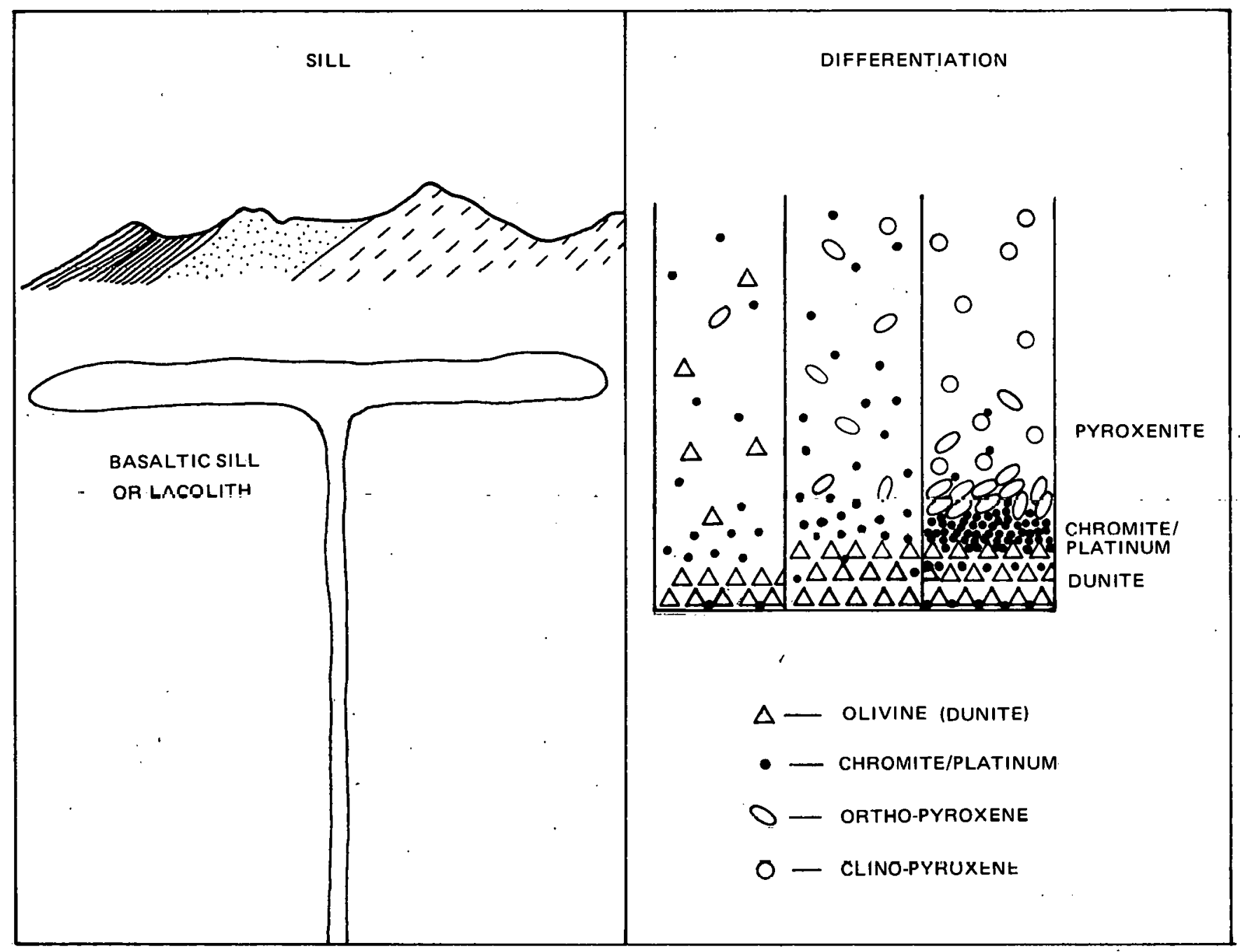

FIGURE 1. Graphical representation of the formation of a hasaltic sill and subsequent concentration of platinum group metals in the chromite band.

a few of the superheavy elements, ${ }^{17}$ the margin of uncertainty was believed too great with regard to properties such as valence states, complexing properties, and solubilities to trust aqueous chemlcal separation and concentration techniques. It was certain, however, that some method of concentration was needed before the application of available alpha and fission counting methods would be feasible.

The method of concentration employed was a hightemperature, molten-lead extraction of the noble (siderophilic) elements from a molten, fluxed ore. This method is particularly well-designed for the concentration of all nobble metals, with the exclusion of all others. The noble elements contained in as much as two kilograms of ore were concentrated inlo silver beads weighing lioni one to ten milligrams. Chemical enrichments of the order of $10^{7}$ were achieved by this procedure.

In general, the procedure was to pulverize the ore to less than 100 mesh and to concentrate the platinum group metals by fire assay. Fire assay is essentially a molten metal exlraction. The pulverized samples were thoroughly mixed with a fluxing mixture that varied with each sample. 


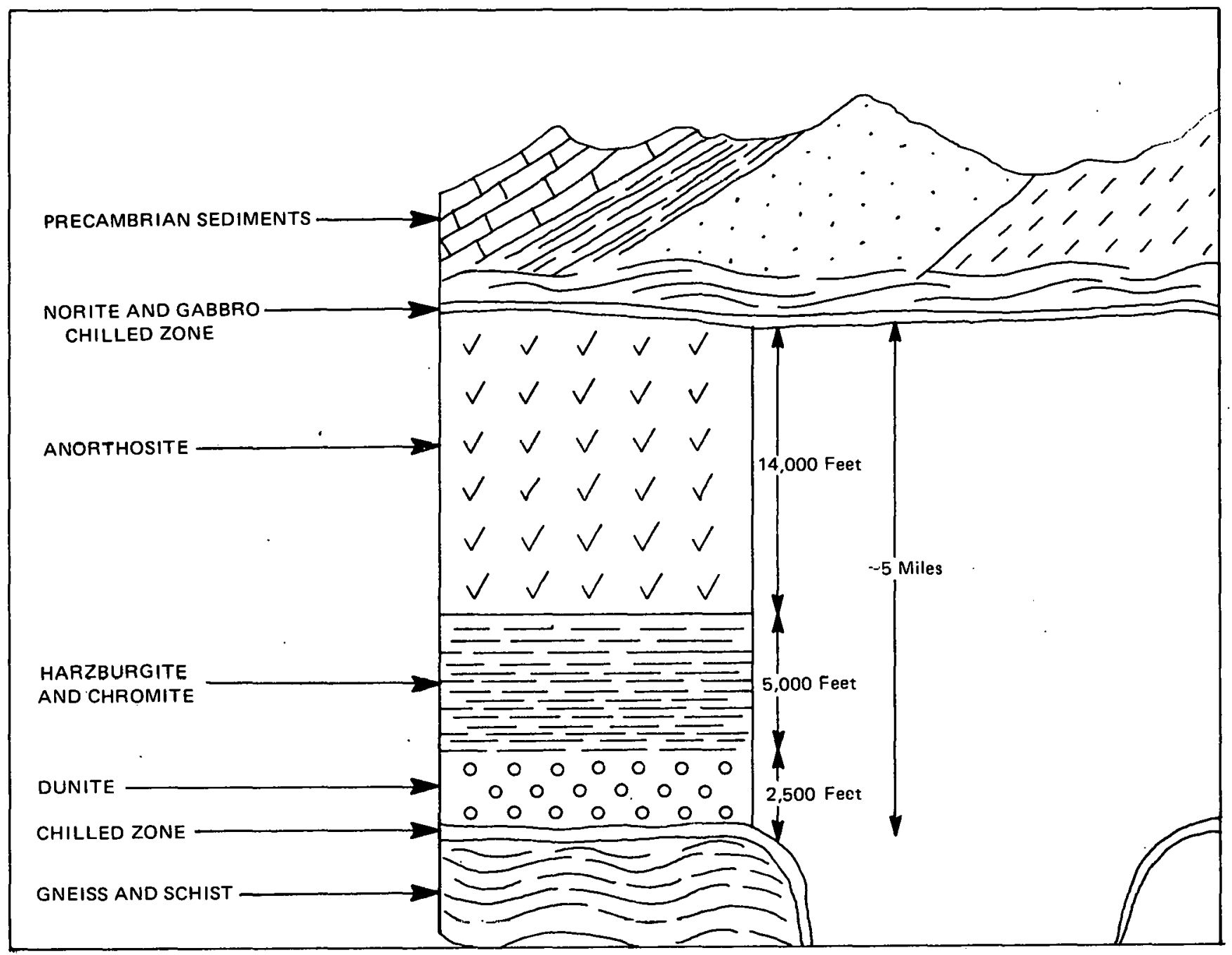

FIGURE 2. Cross section of differentiated sill showing the gabbro and norite zone and the platinum-bearing chromite band.

About 100 grams of litharge and one milligram of silver were added to the sample. The samples were then fused at about $1000{ }^{\circ} \mathrm{C}$. Molten lead, formed by the reduction of the litharge, trickled through the sample and extracted all of the gold, silver, and platinum group metals present in the ore. After cooling, the slag was knocked off the lead button and discarded.

The lead button was then placed on a hot bone ash cupel (a small cup-shaped dish made of bone ash) and held at $1000^{\circ} \mathrm{C}$ until cupellation was complete. This process was carried oul in an oxidizing atmosphere, and the lead oxide formed from the molten lead button was absorbed into the bone ash until only a small bead of silver was left behind. If the platinum group metals were present in the sample, they would be contained in the silver bead. The bead, which weighed only a few milligrams, was then dissolved in nitric acid,* and the resultant solution was evaporated onto a planchet for counting. Planchets of glass, platinum, and stainless steel were utilized in this investigation.

\footnotetext{
*Platinum is soluble in nitric acid in the presence of an excess
} of silver. 


\section{Measurement Techniques}

The counting planchets were placed inside polyethylene caps, and the caps were fitted onto $450-\mathrm{mm}^{2}$ silicon detectors. In this way, the sample was placed within $1 \mathrm{~mm}$ of the detector face, and radiation from any low-level contamination inside the vacuum chamber was shielded from the detector face.

Pulses from the preamplifier were fed into a mixerrouter and then into a 1024-channel Northern Scientific analyzer. This allowed simultanous counting of from one to four samples. Counting times varied with the activity level observed in the sample but were typically one week per sample.

Calibrations were carried out using a californium252 fission standard and a combination neptunium-237, plutonium-239, americium-241 alpha source. Considerable degradation of the alpha and fission spectra occurs because of the mass of the silver and platinum in these samples. For this reason, counts in the pulse height distribution were considered as fission events if their energy was above the maximum alpha energy observed in naturally occuring materials.

\section{RESULTS AND DISCUSSIONS}

Results from approximately one-week fission counts on the samples and from background ranged from 0 to 0.5 and from 0 to 0.2 counts per day, respectively. Repeat measurements on samples whose counts originally appeared above background gave negative results. Based on these measurements, no statistically significant fission activity was observed in any of the samples.

Alpha pulse height spectra from the samples yielded somewhat surprising results. Spectra from the Montana platinum placer were among the most unusual. Two samples were prepared from the platinum placer as follows: Three small platinum nuggets were selected with the aid of a microscope to eliminate any small amount of monazite sand that might normally be carried with a placer sample. These nuggets were dissolved and a portion of the solution was mounted for counting. The remainder of the solution was run through a fire assay before dissolution and mounting.

Alpha pulse height spectra from these two placer samples are shown as A and B, respectively, in Figure 3. The absence of the ${ }^{232} \mathrm{Th}$ (thorium) parent in Spectrum A is puzzling. The ${ }^{228} \mathrm{Th}$ was assumed present since the $5 \mathrm{MeV}$ peak was considerably broader than other peaks in the spectrum. The most logical explanation is that thorium was separated from the sample and radium was not. The ${ }^{228} \mathrm{Th}$ and daughters could subsequently have grown back into equilibrium from the ${ }^{228} \mathrm{Ra}$ (radium) parent.

There are two problems with this explanation. First, it is difficult to explain how thorium could lave been separated from a platinum nugget that has never been in solution. The second difficulty is related to the background of the placer sample. Best determinations reveal the sample was placer-mined about 1870 , placed in a glass vial, and was not removed until this study. The thorium separation must have occurred bcfore the placer was placed in the vial; yet in the intervening 100 years, the ${ }^{228} \mathrm{Ra}$ and its daughters would have decayed away.

Spectrum B also provides unusual results. Similar fire assay runs on uraninite and thorium dioxide samples yielded separations greater than $10^{4}$ for bismuth and polonium, and greater than $10^{7}$ for lead, thorium, and uranium. Comparison of the ${ }^{212}$ Po (polonium) count in Spectra A and B reveals a separation factor of approximately 50 , assuming no decay between the time of separation and count. About 100 grams of lead were added to Sample B before the molten metal extraction; whereas, the final sample mounted for counting contained less than 0.001 milligrams of lead. This amounts to a lead dilution of about $10^{8}$. Assuming the ${ }^{212}$ Po originates primarily from a ${ }^{212} \mathrm{~Pb}$ (lead) parent, the separation factors would indicate little or no exchange of this ${ }^{212} \mathrm{~Pb}$ with the lead employed in the separation.

Spectrum A in Figure 4 shows a repeat measurement made on the second placer sample. Here, the ${ }^{212} \mathrm{Bi}$ (bismuth) and ${ }^{212} \mathrm{Po}$ activities have decayed away. A half-life of $160 \pm 30$ days was obtained 


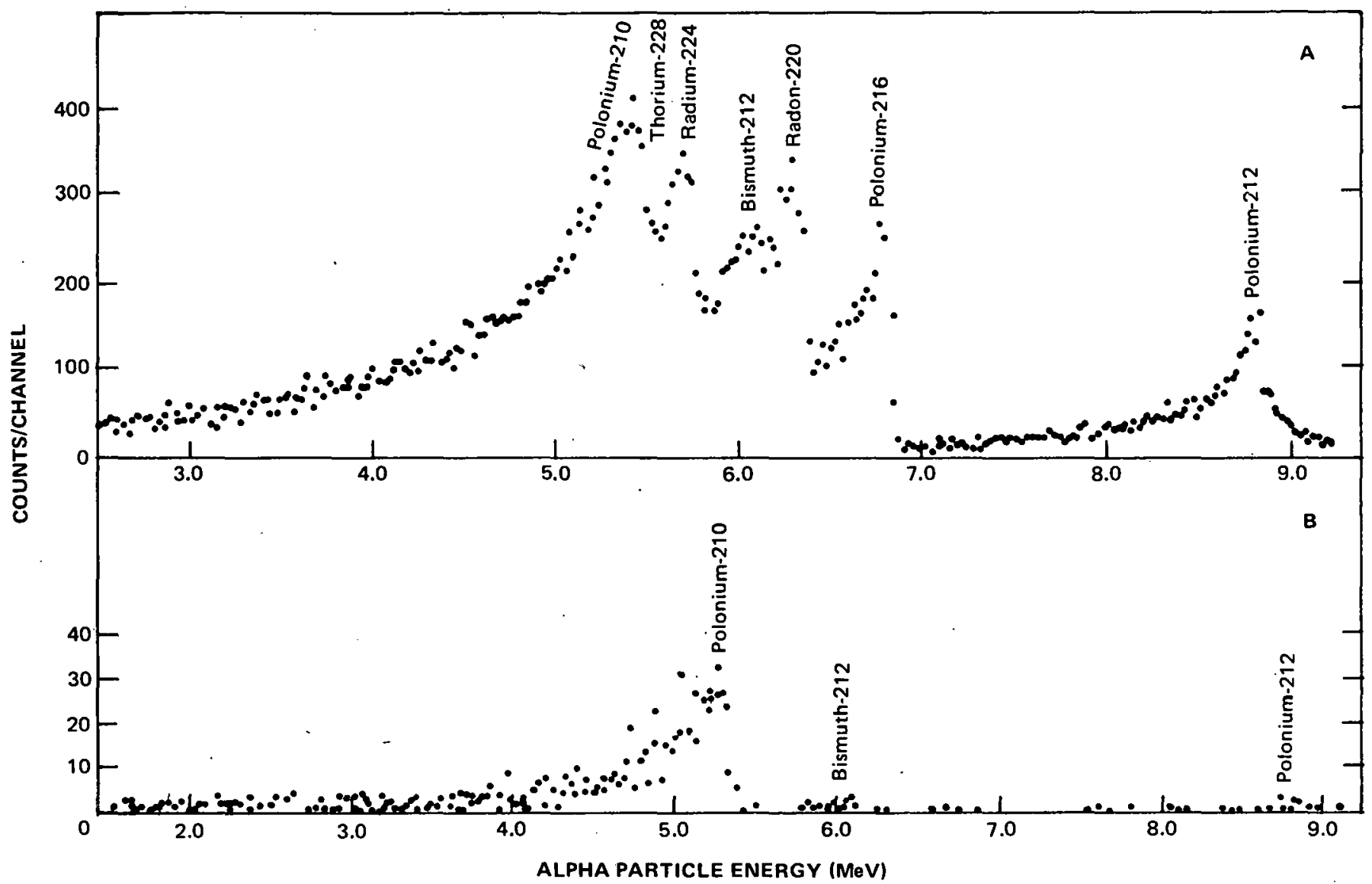

Legerd

Spectrum A: Platinum placer, Butte, Montana.

Six-ray alpha count of a direct

mount from three dissolved platinum

nuggets.

Spectrum B: Platinum placer, Butte, Montana.

Three-day alpha count of a portion

of the sample shown in Spectrum A,

after fire assay concentration.

FIGURE 3. Alpha Pulse Height Sper.tra frnm Two Placer Samples.

for the $5.3 \mathrm{MeV}$ activity, which is in reasonable agreement with the 138 day half-life of ${ }^{210} \mathrm{Po}$.

Spectrum B in Figure 4 was obtained from the Merensky Reef, South Africa sample. This spectrum is similar to one of the spectra shown by Marinov, et al. $;^{18}$ however, statistics are insufficient to determine whether thorium and its daughters are also present.
Spectrum C in Figure 4 was obtained from one of the Stillwater, Montana samples. The count was begun 66 hours after the fire assay separation. This amounts to six half-lives for the ${ }^{212} \mathrm{~Pb}$ parent of the ${ }^{212}$ Po activity. Combining this with a lead dilution of $6 \times 10^{9}$ again yields untenable conclusions with regard to the observed ${ }^{212}$ Po activity.

Spectrum C is similar to spectra obtained from the majority of samples; i. e., a low count rate with 


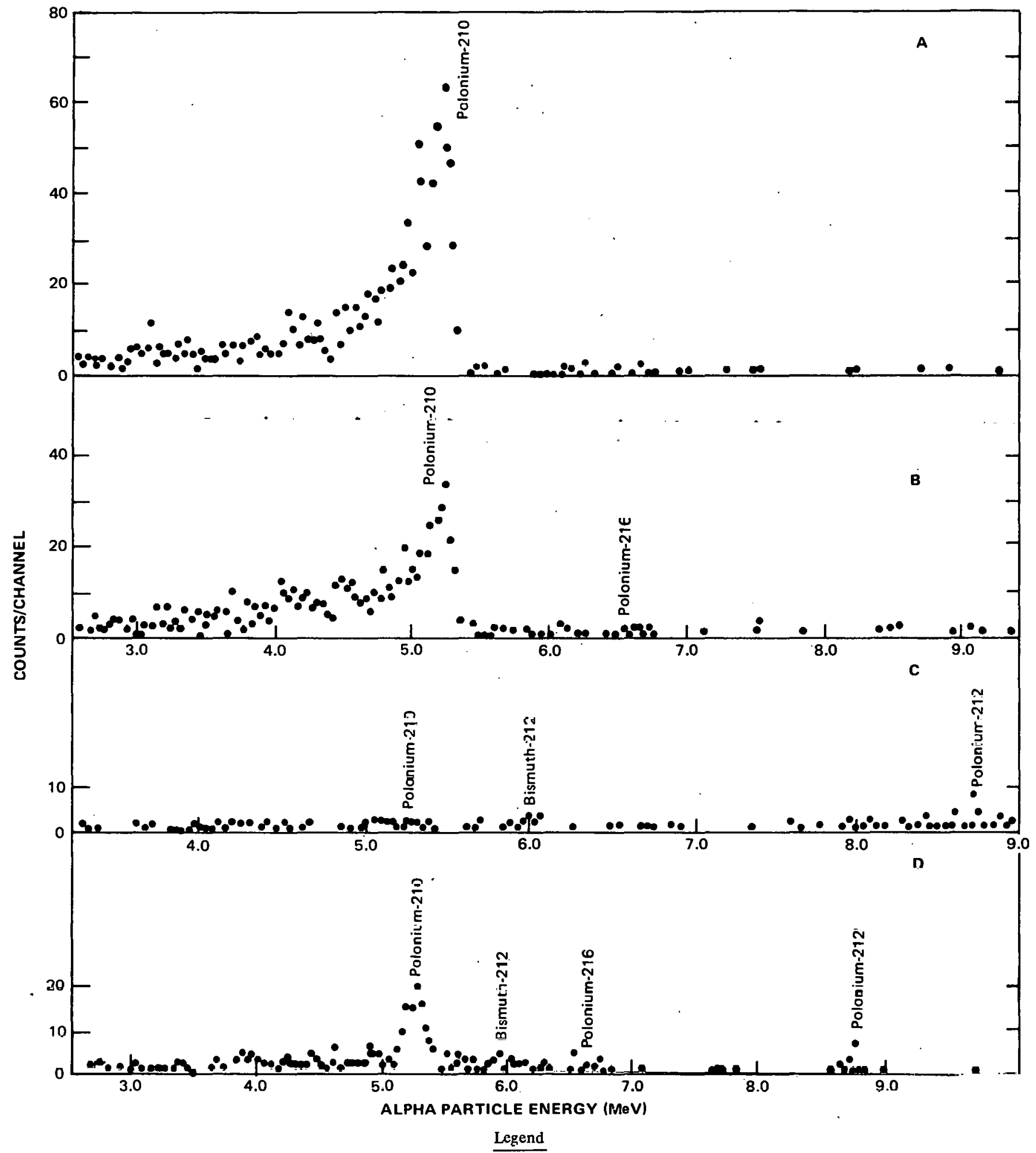

Spestrum A: Platinum placer. Butte. Montana, Six-day alpha count of the sample shown in Figure 3, Spectrum $B$ after three months decay.

Spectrum B: Merensky Reef, I'ransvall, Africa. Five-day alpha count after fire assay concentration.

Spectrum C: Stillwater Chromite, Butte, Montana. Seven-day alpha count after fire assay concentration.

Spectrum D: Copper King Mine, Cook City, Montana. Sevenday alplid count after fire assay concentration.

FIGURE 4. Alpha Pulse Height Spectra of Various Samples. 
a small ${ }^{212}$ Po peak. The 6.0 and $8.8 \mathrm{MeV}$ peaks were present only if counting was begun shortly after the fire assay separation, although Spectrum C exhibited higher that usual ${ }^{212} \mathrm{Bi}$ and ${ }^{212} \mathrm{Po}$ activities.

Spectrum D. in Figure 4 was obtained from the Cook City sample. This is the only sample run through the fire assay where a detectable activity, other than polonium and bismuth, may be present.

Fire assay concentrations were carried out on several nonplatinum-bearing samples. No discernible peaks were observed in alpha spectra obtained from most of these samples or from samples obtained from fire assay runs using only reagent materials. Several attempts were also made to volatilize the ${ }^{210} \mathrm{Po}$ by flaming some of the samples; however, no appreciable decrease was observed in the 5:3 $\mathrm{MeV}$ activity from any of these attempts.

The $5.3 \mathrm{MeV}^{210}$ Po activity appears related to the amount of platinum present in the samples run through the fire assay separations. While not directly proportional, the ${ }^{210}$ Po activity was highest in the sample containing the highest concentration of platinum, second highest in the sample containing the second highest concentration of platinum, and so forth.

Difficulties are always encountered in explaining any observed ${ }^{212} \mathrm{Bi}$ and ${ }^{212} \mathrm{Po}$ activities if one considers the lead dilution factor in the fire assay concentration. One possible explanation for this would involve the formation of a stahle, hightemperature platinum polonide.

The formation of platinum polonides during the lead oxidation-separation could then lead to the observed activities as follows: The platinum polonide could be selectively formed with ${ }^{216} \mathrm{Po}$. In less than one second, the ${ }^{216}$ Po would decay to ${ }^{212} \mathrm{~Pb}$; however, if this ${ }^{212} \mathrm{~Pb}$ was contained in a platinum globule, it would have little chance of being diluted with the molten lead in the surrounding medium. The observed result would be ${ }^{212} \mathrm{Bi}$ and ${ }^{212} \mathrm{Po}$ activities decaying in equilibrium with a ${ }^{212} \mathrm{~Pb}$ parent. The ${ }^{210} \mathrm{Po}$ could also originate in a similar manner. This process would also explain the increased polonium activities observed in the samples containing the higher concentrations of platinum, but the process does not offer a logical explanation for the observed results.

\section{CONCLUSIONS}

An estimate of the abundance of Element 110 can be made from the negative fission counting results. The Stillwater and Merensky Reef chromite ores can be used, providing one makes the following assumptions:

(1) Ekaplatinum was concentrated similarly to chromium and platinum in the chromite ore. The ratio of chromium in these chromite ores, formed after differentiation to that in the gabbro samples, was $5.6 \times 10^{3}$ and $2.5 \times 10^{3}$. These values should be lower limits for the enrichment of ekaplatinum by natural processes in these two complexes.

(2) Ekaplatinum is a noble element and follows the noble elements in the fire assay procedure. In the Stillwater chromite sample, 600 grams of ore were reduced to a $9.9-\mathrm{mg}$ silver-platinum bead, giving an enrichment of $6 \times 10^{4}$. In the Merensky Reef chromite sample, 450 grams of ore were reduced to a $3-\mathrm{mg}$ silver-platinum bead, giving an enrichment of $1.5 \times 10^{5}$.

Using a spontaneous fission half-life of $10^{y}$ years, the following estimates on the abundance of Element 110 can be made:

\section{Stillwater Chromite}

(a) $110<10^{-14} \mathrm{~g} / \mathrm{g}$ of ore

(b) $110<2 \times 10^{-18} \mathrm{~g} / \mathrm{g}$ of magma

Merensky Reef

(a) $110<5 \times 10^{-15} \mathrm{~g} / \mathrm{g}$ of ore

(b) $110<2 \times 10^{-18} \mathrm{~g} / \mathrm{g}$ of magma 
Studies on the other samples typically have yielded results of less than $10^{-14}$ to $10^{-15} \mathrm{~g} / \mathrm{g}$ of ore. Enrichments by natural processes were not available; therefore, estimates for magmatic abundances could not be made.

Although alpha spectra from several samples yielded results that are difficult to interpret, the authors believe these results do not offer any positive evidence for the existence of superheavy elements in nature.

\section{REFERENCES}

1. W. J. Swiatecki and W, D. Myers. Nucl. Phys. $81: 1$. (1066)

2. S. G. Nilsson, C. F. Tsang, A. Sobiczewski, Z. Zymanski, S. Wycech, C. Gustafson, I. Lamm, P. Möller, and B. Nilsson. Nucl. Phys. A131:1. (1969)

3. U. A. Muzychka, V. V. Pashkevich, and V. M. Strutinskii. Yadern. Fiz 8:716. (1969)

4. J. Grumann, U. Mosel, B. Fink, and W. Greiner. Z. Physik 228:371. (1969)

5. S. G. Nilsson, S. G. Thompson, and C. F'. 'I'sang. Phys. Lett. 28B:548. (1969)

6. J. J. Wesolowski, W. John, R. Jewell, and F. Guy. Phys. Lett. 28B:544. (1969)

7. H. Meier, W. Albrecht, D. Bösche, W. Hecker, P. Menge, A. Ruckdeschel, E. Ungcr,
G. Zeitler, and E. Zimmerhackl. Z. Naturforsc 25a:79. (1970)

8. W. Grimm, G. Herrmann, and H. D. Schussler. Phys. Rev. Lett. 26:1040. (1971)

9. E. Cheifetz, R. C. Jared, E. R. Giusti, and S. G. Thompson. Phys. Rev. C6:1348. (1972)

10. P. B. Price, R. L. Fleischer, and R. T. Woods. Phys. Rev. C1:1819. (1970)

11. G. N. Flerov and V.P. Perelygin. At. Energ. (USSR) 26:520. (1969)

12. A Wyttenbach. Z. Naturforsch 25a:307. (1970)

13. V. E. Viola, Jr: "On the Production of Nuclides with $A>250$ in Steller Nucleosynthesis," MNC-3783-0001, University of Maryland, March 26, 1969.

14. D. N. Schramm and W. A. Fowler. Nature $231: 103$. (1.971)

15. W. M. Howard and J. R. Nix. Nature 247:17. (19'/4)

16. O. L. Keller. Oak Ridge National Laboratory, Oak Ridge, Tennesiee. Private communication. 1970.

17. O. L. Keller, J. L. Burnett, T. A. Carlson, and C. W. Nestor. Phys. Chem. 74:1127. (1970)

18. A. Marinov, C. J. Batty, A. I. Kilvington, G. W. A. Newton, V. J. Robinson, and J. D. Hemingway. Nature 229:464. (1971) 